\title{
Methods of Management of Public Financial Resources
}

\author{
Kamilla G. Abazieva
}

Don Cossack State Institute of Food Technology and Economics (branch) of Federal State Budgetary Educational Institution

Svetlana N. Goncharova

Don Cossack State Institute of Food Technology and Economics (branch) of Federal State Budgetary Educational Institution

\author{
Ludmila P. Maslennikova
}

NSEPI HE Moscow Academy of Entrepreneurship under the Government of Moscow, Rostov-on-Don, Russia

Dmitry I. Stratan

Don State Technical University, Taganrog, Russia Email: eldirect@mail.ru, pogojeva-sng@mail.ru

\section{Doi:10.5901/mjss.2015.v6n3p60}

\section{Abstract}

December 2012 marked 20 years since the formation of the Federal Treasury and throughout this period the Treasury of Russia has always been at the forefront of innovation processes. In this article the use of tools aimed to improve the Federal budget execution in terms of management of liquidity of Unified account of the federal budget (Treasury Single account) are studied. The existing mechanism of liquidity management proves its effectiveness and, consequently, the ways of its development and improvement are in existence. The liquidity of the Single Treasury account is the ability of the relevant Treasury single account in a certain period of time to make timely payments of public administration sector. Ensuring the liquidity of the Single Treasury account are developing in the following areas: the functioning of the Single Treasury account, forecasting and cash planning funds from the Federal budget, management of funds of the Federal budget. The implementation of these directions will set a new standard in the process of formation of system of liquidity management of Single Treasury account, will allow in time to assess the liquidity of the Treasury and to make informed decisions on its regulation, will simplify many business processes in the management of public financial resources.

Keywords: Single treasury account, outturn of the budget, liquidity of Single account, Cash Managment, cash planning.

\section{Introduction}

The public authorities in the process of implementation of various government functions provide the necessary regulation in the sectors of the national economy and the social sphere through funding and reallocation of funds provided for these purposes in the budget, the relevant provisions of the Budget message of the President of the Russian Federation to the Federal Assembly of the Russian Federation on budget policy for the corresponding three-year period, the main indicators of socio-economic development of the Russian Federation and the main directions of the budget policy. In the field of public Finance management new instruments of budget planning and financing, should be actively introduced, which causes the improvement of individual stages of the budget process, including the execution phase of the budget, which will result in the efficient use of public financial resources. The efficient use of public resources is one of the most important problems which are solved by authorities of the state at the present time. The effectiveness can be achieved by the continuous increase of budget expenditures, i.e. to have "economies of scale", and with the same quality of public services or (in some cases) of its decrease. (Peacock S., 2008). The key point of the anti-crisis plan of the state is the optimization of budget expenditures at the expense of inefficient spending, the performance of public obligations of all levels of government and the concentration of resources on priority areas. Because of this investigation in search of tools for improving the management of public financial resources and liquidity management Single Treasury account in the framework of the implementation of anti-crisis route support of the Russian economy in 2015-2016 is well-timed.

The purpose of a scientific article is to provide a method of creating sovremnnyh treasury single account that can 
solve such problems as:

1. Promptly evaluate the liquidity of the Treasury and to make informed decisions on its regulation.

2. simplify many business processes in the area of public financial management.

The objectives of this research is to discuss and propose ways of making higher these problems.

\section{Literature review}

State payments take the main role of the national payment system that have a huge impact on economic growth and monetary policy.

Table 1. Single Treasury account (STA)

\begin{tabular}{|l|l|}
\hline Account & Name \\
\hline 40101 & Income distributed by the Federal Treasury bodies between the levels of the budgetary system of the Russian Federation \\
\hline 40105 & Federal funds \\
\hline 40116 & The funds for the payment of cash to the recipients \\
\hline 40201 & The funds of budgets of the territorial entities of the Russian Federation \\
\hline 40204 & Funds of local budgets \\
\hline 40302 & Funds temporary used by budgetary organizations \\
\hline 40816 & Budget of the Common state \\
\hline 40501 & Funds of enterprises in Federal ownership. Financial institutions \\
\hline 40601 & Organizations account located in the state (except Federal) ownership. \\
\hline 40701 & Accounts of non-governmental organizations. Financial institutions \\
\hline
\end{tabular}

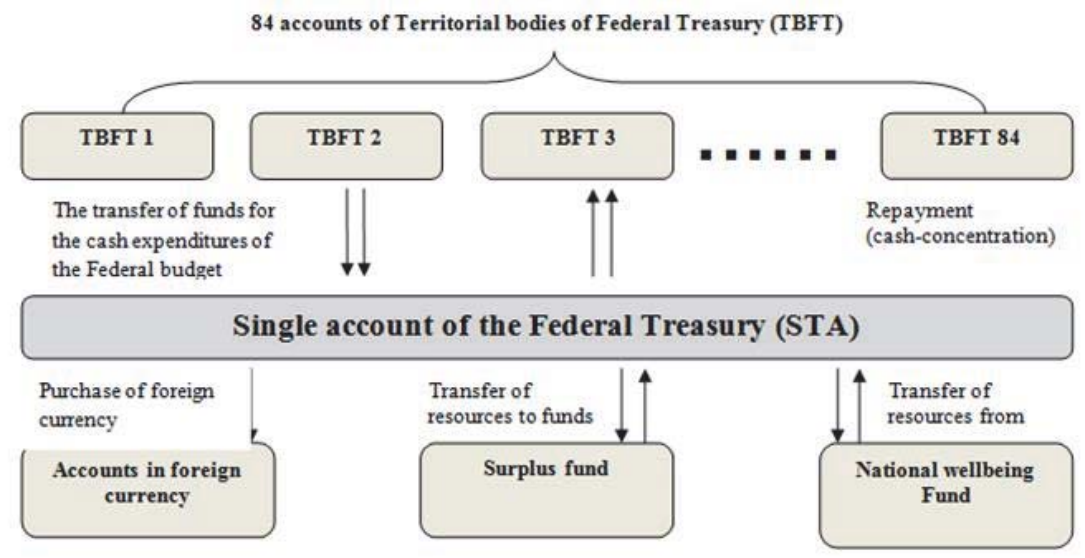

Figure 1. Single Treasury account (STA)

The functioning of the system of budget execution is carried out taking into account a number of fundamental principles, which traditionally include General principles of the organization and build of a budget system, namely: the principle of independence of the budget, the principle of budget transparency, the principle of separation of revenues, expenditures and sources of financing the budget deficit and other principles. The basic principles are reflected in the legislation of the majority of both Federal and unitary states. (Premchand, A., 1994).

The efficiency of government payments depends on the functioning of the Single Treasury account (STA).

STA is treasury account at the Central Bank of the country, which consolidates the cash position of the state (Treasury Single Account, 2010).

STA of the budget represents an actual and, as noted, constantly improving structure, ensuring the transparency of the movement of public finances. The operation of the STA of the Federal Treasury is presented in the following figures $(2,3,4)$. 


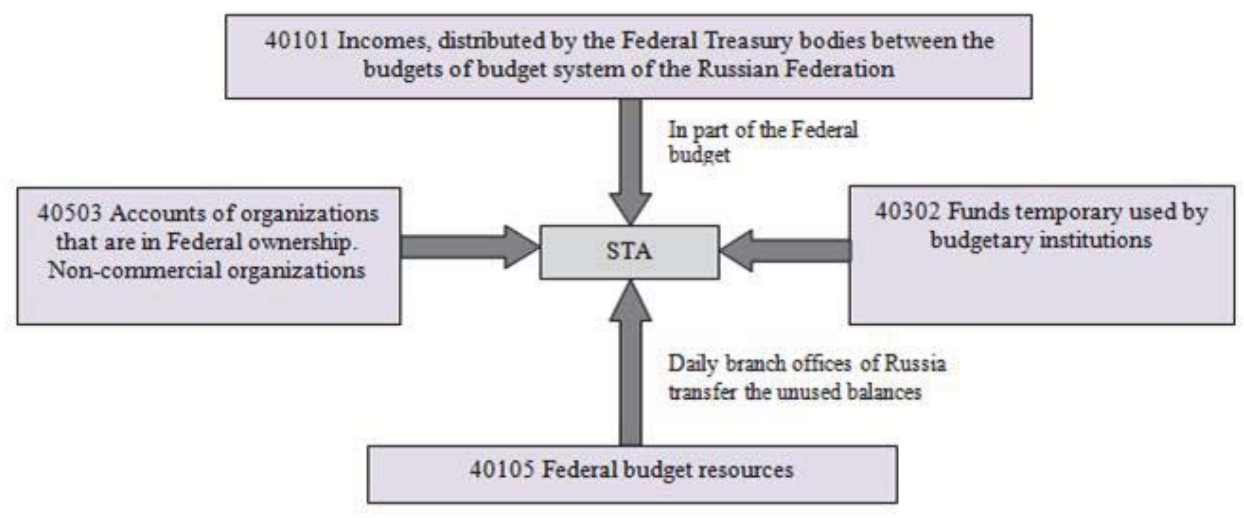

Figure 2. Transfer of funds of department of the Federal Treasury to the STA from its open accounts

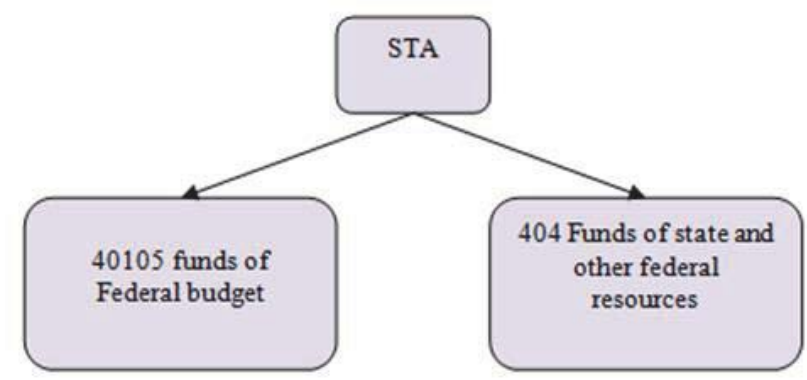

Figure 3. Writing off of amounts from the account of STA to accounts of departments of Federal Treasury

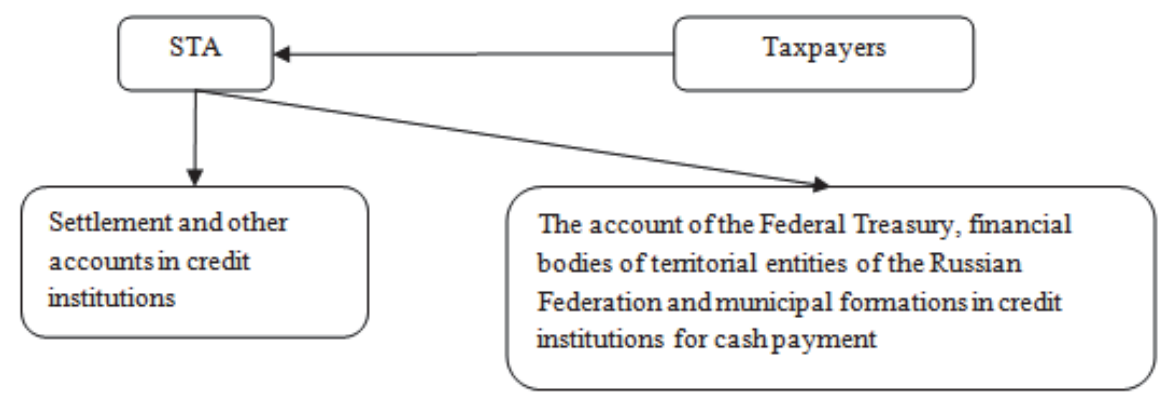

Figure 4. Intended functioning of the STA in 2017

The performance of the Single-account budget contributes to the implementation of effective fiscal policy, allows administrate the free budget Finance of him. Call for funds is a mechanism of reinforcement of a Unified account of the Federal budget for the implementation of performance of previously scheduled commitments. Under this mechanism the funds that are in the account of № 40302 «Funds temporary used by budgetary institutions», № 40501 «Accounts of organizations that are in federal ownership are used. Financial organizations» with their subsequent return to the specified account (figure 5). 


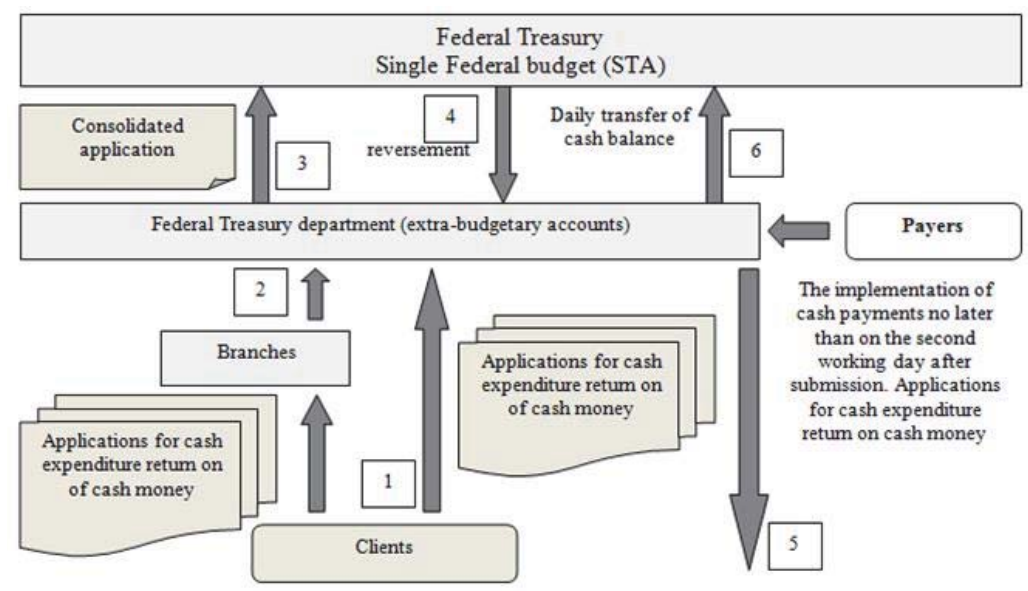

Figure 5. The scheme to attract temporarily available extra budgetary funds

In case of costs implementations and cash payments providing necessity Federal Treasury transfers all necessary money from the Federal Treasury Single Account to accounts, there temporary spare money was involved.

This mechanism realization would be impossible without the Budget Single Account, which provides the accumulation of federal budget money, which allows to get actual information about budget money state and hence to realize rational planning of its usage. That provides the timely payments on the expenditure obligations of public and legal institution. In addition, the attraction of free funds from the budget accounts to the single account of the federal budget enables the State to cover cash gaps formed in the course of the year.

Mobilization of domestic resources of the State is necessary for the timely implementation of financial operations, rapid response to economically adverse events and constant movement of budget funds for their use insurance.

\section{Methods and Medium}

One of the main liquidity management mechanisms of Federal Budget Single Account is the usage of cash planning and financial forecasting procedures during the execution of the federal budget.

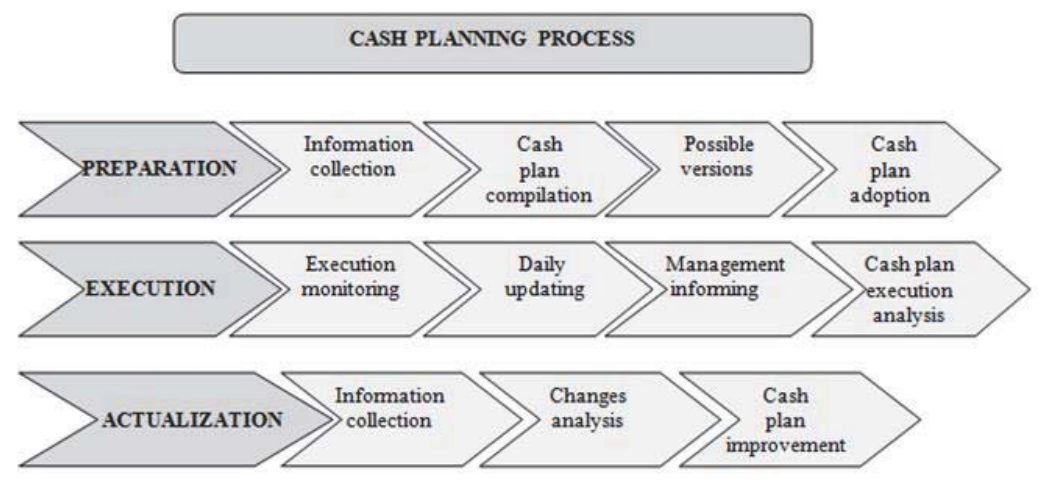

Pic 6. Cash planning process scheme

Cash planning - is a unique planning tool of monetary circulation in the country, allowing to implement a system of efficient operations management of state financial resources that will ensure the transition to the centralized management of STA liquidity.

Financial forecasting provides the calculation of the possible volumes of all cash receipts and payments from the budget in a certain time period in the future, as well as the comparison of actual results obtained with the forward-looking indicators.

The main result of cash planning is a cash plan, serving as cash receipts and cash payments from the budget in 
the current fiscal year prediction. (Emelianenko A.V., 2011).

In performing functions for the cash plan development, refinement and maintenance Federal Treasury designs a cash plan for the current fiscal year with monthly detail; cash plan for the current calendar month with weekdays detailing; makes cash plan improvements for the current fiscal year with monthly detail; receives and processes the information provided for the formation and refinement of the cash plan of the federal budget for the current fiscal year.

The cash plan index system allows to analyze this year state of the STA to ensure the effective implementation of the budget by budget process participants.

Thus the ratio of federal budget cash receipts and cash payments allows to define the minimum acceptable level of budgetary funds for STA as well as the amount of federal budget temporarily spare funds at a time (pic. 4).

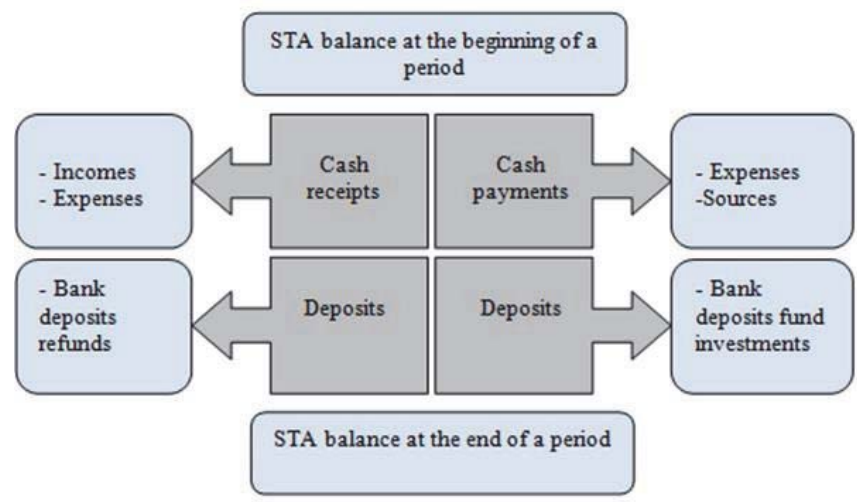

Pic 7. Federal budget execution cash plan structure

Summing up, it should be noted that the result of the effectiveness of the use of the described mechanism cash planning are affected by the executive discipline of the budget process participants, namely the timely submission of accurate and complete information, as well as the introduction of new technological approaches to cash planning.

So, despite the positive examples of evaluation practices in different countries, it should be noted that today the problem of existing programs effectiveness estimation is not fully resolved and there is no country in the world that would have been completely satisfied with their efficiency indices. (Bartle, J.R., 2001). Therefore, the issues of reliability and relevance of the indicators continue to be among the most important.

It is clear that the phased planning performance evaluation indices should include not only quantitative but also qualitative aspects.

Effective functioning of the cash planning model contributes to the rational and operational financial management in the public administration sector, which in its turn helps to minimize the Sovereign Wealth Funds involvements for the federal budget balancing, acquire additional interest earnings from bank deposits spare federal budget funds and use new technologies for additional reserves involvement.

The System of budget payments reforming by 2017 and the transition to a Single treasury (bank) account would require targeting of STA cash balances for the effective management of excess liquidity to generate additional income.

Cash planning and forecasting for STA policymaking in the new environment and the necessity of strict execution of all activities planned by the Treasury Russia strategy map in 2015 are of priority importance. (Artyuhin R.E., 2014).

\section{Results and Discussions}

\subsection{Federal budget cash management}

Even today the Treasury of Russia provides the required minimum level of funds in the Single account of the federal budget (STA) and receives additional federal revenues due to the management operations of spare cash balances of STA.

STA liquidity management is carried out in various directions (Pic 8).

Budget accounts liquidity Management (L.V. Shubina, 2013) is carried out in a strict accordance with the budget legislation, which provides that a relative lack of funds authorized federal authorities are to mobilize borrowed funds in the credit market to cover all the necessary budgetary expenditure. 


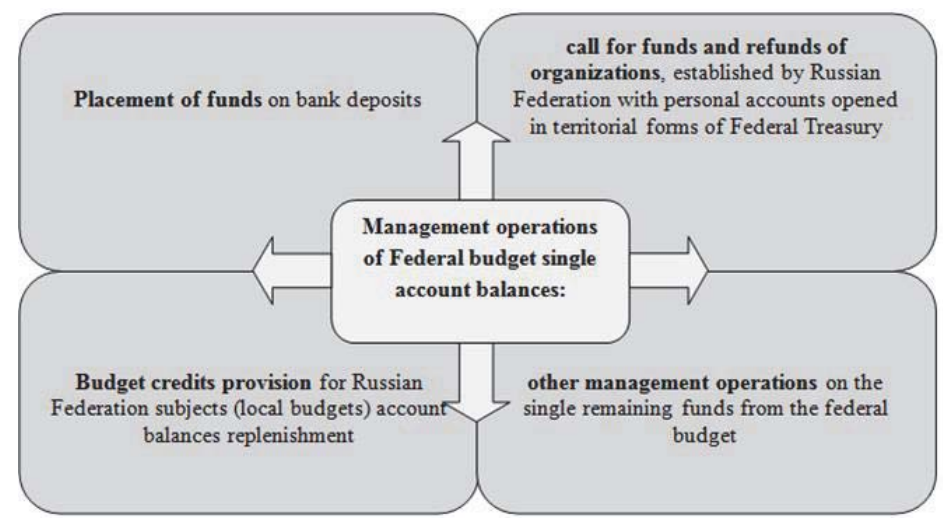

Pic. 8. Federal budget funds management

In 2014 in the conditions of unstable situation on the financial markets one has been managed to clearly organize the federal budget placement on bank deposits. Altogether there was 80 credit institutions applications selections, which is of 1.2 times more than the same period of 2013.

Estimated income from the placement of the federal budget on bank deposits will amount to about 35.2 billion rubles and 2.9 billion rubles will come in 2015 from the federal budget placed in 2014.

As part of anti-crisis measures aimed at providing liquidity to the banking sector in terms of sanctions imposed on the large state-owned banks, for Russian Ministry of Finance individual solution there has been 170 billion rubles placed on bank deposits. From these transactions on the federal budget additional 4.8 billion rubles will go in 2014.

The STA federal budget spare balance, including achieved by carrying out operations for unrestricted STA balances of public administration sector targeting, creates the conditions for the provision of short-term loans of the federal budget to the budgets of subjects of the Russian Federation and local budgets to cover temporary cash shortages at a rate below the refinancing rate.

Since the beginning of 2014 I a new mechanism of territorial bodies of the Federal Treasury budget credits extension for the regional budgets account balances replenish (budget loans) was started. As of September 26, 201456 agreements with the authorized organs of the Russian Federation subjects were signed, 173 budget loans totaling 376.6 billion rubles were provided. Sum total the federal budget received 259.6 million rubles by providing budget loans.

Given innovation implementation on the one hand allowed the subjects of the Russian Federation to replenish cash gaps arising from short-term budgetary credits with a new mechanism of subsidies and subventions providing from the federal budget. On the other hand, it has contributed to reducing the debt ratio on regional budgets in terms of substitution of the Russian Federation subjects commercial credits with budget ones.

In 2015 it is planned to test the mechanism of budget loans to municipalities.

This will start the mechanism of the Federal budget single account balance management operations in terms of purchase (sale) of securities under sale and repurchase agreements with credit institutions.

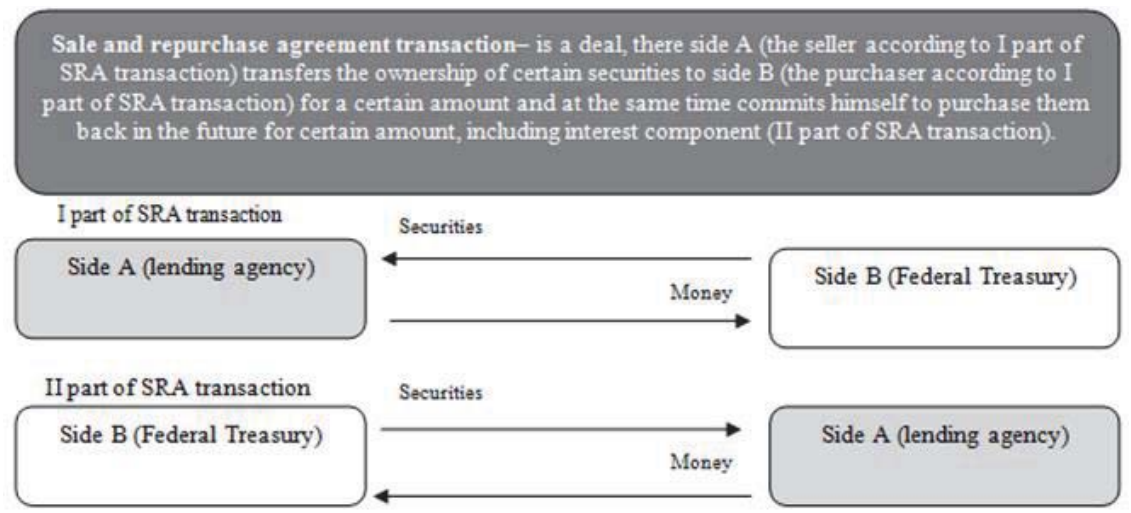

Picture 9. Securities operations according to SRA transactions 
The effect of the placement of the federal budget on bank deposits on the basis of the exchange:

- $\quad$ regular and frequent funds placement is provided;

- supply to demand taking into account the data about the state of the financial markets is approximated;

- limpid mechanism of competitive selection of credit institutions applications is proposed;

- a certain minimum size of the offering funds for placement is guaranteed;

- different maturity range of deposits placed in a calendar month is offered;

- modern efficient trading platform (exchange) is used;

- Federal Treasury deposits use as a financial market "beacon".

Liquidity management mechanisms are not enough frequency used at the level of the budgets of subjects of the Russian Federation and municipalities. In making decisions, aiming at their introducing into a separate public legal institution, one should take into account the possible economic risks, the weightiest of which are critically low STA balances.

\subsection{Cash Management tools application}

We believe that one of the necessary conditions of Treasury Single Account liquidity increase is Cash Management tools usage.

Cash Management term is widely spread abroad. Traditionally one defines it as a system of banking technologies for the corporate client financial flows management. In accordance with that, commercial banks are its main users. However today the system of Cash Management is used by Russian Treasury as an innovative payment instrument.

The main components of the Cash Management system products are: management of bank accounts, liquidity (management of bank balances), the interest rate; settlement and cash services; information services; electronic banking, card projects - acquiring (a procedure which provides settlement operations execution with payment cards). (Syarheenko N.S., 2014). New technology corresponds with treasury functions. Cash Management, in fact, is the basis of the Federal Treasury.

Cash Management instruments application aims in efficient government bankroll managing with the help of STA.

The main directions of Cash Management development in the Federal Treasury system are following: accumulation of funds in the single treasury account; improvement of mechanisms of control of the unencumbered balances of budget funds and processes of electronic services; increase of the speed of payments and cash management services qualitative characteristics of the budget system of the Russian Federation performance; minimization of cash circulation; and the development of information systems and technologies (IT systems) designed to serve as a cash services for public administration management.

This will ensure the maximum concentration of public sector funds on the Single treasury account, reduction of the amount of government borrowing and interest costs associated with them; increase of revenues within the placement of temporary spare funds.

To achieve these goals a number of activities requires: competent cash planning (especially in the main managers of budgetary funds); implementation of active operations in the financial market; revenue process control and all funds coming into the state treasury accounting ; timely and full budgetary payments ensuring.

Initial results are already achieved. A new mechanism of intergovernmental transfers and budget loans for subjects of the Russian Federation budgets account balances replenishment (local budget) is created. Spare cash balances targeting operations are carried out. They are to control the size of the daily balance in the single treasury account by monitoring the Federal Treasury for cash servicing of budget obligations. Targeting of the unused balance of the reserve fund and so on is performed in order to extract additional revenue due to operations in the financial market.

Note that the STA call for funds operations are comparable with the following banking product as the system Cash Pooling.

This system is a centralized cash management within the group. Differently, Cash Pooling - is a system for management of multiple accounts opened in the bank with their balances going to one account (cash concentration). However, the introduction of such commercial tools in the area of public finance management requires detailed study, including:

- mathematical apparatus for liquidity ratios calculation;

- the budgetary accounting transformational changes, associated with the individual balance sheet positions on market mechanisms isolation;

- planning and forecasting improvements, in particular the introduction of additions to the cash plan on these items; 
- a system of risk events and their evaluation development.

In 2017 Russia Treasury should become a "Treasury - Bank", using modern electronic resources at that.

Work on the development of software products is continuing. The websites for the distribution of the information about the state (municipal) institutions (www.bus/gov.ru), orders for goods, works and services for state and municipal needs (www.zakupki.gov/ru) are used.

Web portal of electronic payments of population with general government organizations (pay.budget.gov.ru) by means of plastic cards, e-wallets, mobile phones is improving.

Public informational system for regional and local payments (PIS RLP) is developing.

PIS RLP federal portal is a key information contributor for general government segments on receipt of budget revenues within the interagency electronic interaction system (IEIS). Federal Treasury creates modern client-directed payments organization service model.

First of all we are talking about strengthening of the autonomy and responsibility of ministries and departments for the results of the programs implementation. One can say that the software architecture of the budget involves the construction of "chain of responsibility» (Barilari, A., Bouvier., M.), when on the federal and regional level the specific individuals responsible for the results of the implementation of programs / subprograms are defined. An important condition for efficiency is the existence of direct relationship between the activities and their evaluation indices.

Thus, information and telecommunication systems of the Federal Treasury (and its subsystems) on the scale, the list of the variables indices, its database valume, architecture complexity, internal links diversity and territorial branching can be attributed to the significant number of public information systems which users are authorities and government of all levels, businesses entities, budget process subjects, citizens.

To implement a Cash Management a new information systems is required. Developed IT systems are a prerequisite for Cash Management Services. A number of such systems are already successfully operating.

For example, centralized middleware product "Automated Federal Treasury System" (AFTS), aimed at the integration of accounting information within a subject of the Russian Federation, allowed not only to hold a series of optimization measures in the organizational structure of the Federal Treasury, but also significantly increase the transparency, information quality, as well as efficiency of its disclosure to external users.

AFTS web portal became principally new software for other budget process participants (subsystem for external users). It allows Treasury customers to implement information interaction with treasury bodies on-line with the Internet using.

Federal Treasury generates client-directed payment organization service model.

Efficiency and budget funds turnover are important elements, influencing the effectiveness of the Single Treasury Account. Federal Treasury bodies are included in the associated partners of Banking Electronic Speed Payment System (BESPS). BESPS implementation allowed accounts reinforcements in the current working day, minimizing even shortterm diversion of funds from the Treasury Single Account, as well as increasing the efficiency of payments from the federal budget.

The basis of the Cash Management product line of the Federal Treasury body at the moment is for accounting services in the context of budget classification codes and budgets cash flow control. However, the development of individual products in the provision of additional treasury services for clients can be compared with some banking services.

Given operations are comparable to direct debit bank services (eng. Direct Debit). They allow to debit the customer account on behalf of the bank customer. Such a method is widely used in many countries (United Kingdom, Ireland, Israel, Germany, the Netherlands, Japan, Australia), although the payment technologies vary. In the context of the Russian treasury system this method can also be successfully developed.

\subsection{State payment system operating risks management}

While operating, certain specific risks appropriating to the state payment system arise. The risk of the state payment system can be defined as the probability of deviation of operation of the public payment system from the expected (planned) results for the worse or as the negative situations (trends) occurrence which causes damages (loss) of the participants of the state payment system.

Credit risk, liquidity risk, legal and operational risks apply to the main types of risks peculiar to the state budget payment system. When the organization and functioning of the state of the payment system must necessarily take into account the risks and analyzed the risk factors for the emergence of new risks and the state of the payment system in order to develop and implement measures to minimize the risks or leveling their negative effects. 
During the state payment system organization and functioning one must necessarily take into account the present risks and analyze the present risk factors for the new risks occurrence and in order to develop and implement measures to minimize the risks or leveling their negative effects.

In our opinion, the key aspects of effective risk management are:

- development of a common policy of the subject of the Russian Federation, which defines the principles and procedures of the risk management system of the state payment system (as part of fiscal policy);

- $\quad$ institution-building (the Risk Management Committee (Department));

- $\quad$ the development of a risk management program of the state payment system;

- Monitoring and analysis of the effectiveness of risk management of the state payment system.

The risk management process consists of three stages:

1. Problem statement: risk identification, the scale of risk determination;

2. Problem solution: risk assessment, risk reduction (minimization);

3. Monitoring and control.

STA must have an effective system of state payment system risk control and management. It will help to make right management decisions and improve the effectiveness of problem activities of the Treasury.

As of today, a system of performance assessment is built in the Federal Treasury bodies. Great work on information collection and analysis about the quality of work units and their risk capacitance identification is taken place.

Under the internal risk the impact of external factors on the performance indicators is implied. To manage them helps functioning improvement and influence on the existence of external risks (i.e. the external factors).

Let's illustrate by an example the experience of the Federal Treasury Administration in the Rostov region (hereinafter - Administration). In the pattern of risk value determining the Administration systematically carried out analytical work on the basis of data on the results of the functions / tasks of structural subdivisions.

This takes into account the following violations:

1) identified by structural units during internal control activities;

2) identified by in audits conducted by the Internal Control and Audit Office.

The administration analyzes and takes into account the violations committed by the structural units of both the current rating period and in prior periods. This approach is used as a motivational tool of federal civil servants in order to improve the efficiency of their activity. In turn, the structural units effectiveness assessment is based on the relevant civil servants effectiveness assessment. To order the process the decision to develop appropriate risk management procedures was made. The main components of which are:

- $\quad$ risk management at the level of structural units;

- internal quality risk management audit conducted by the internal control and audit.

The key structural components of the Order include risk maps development, represents a set of spreadsheets with certain indicators (the level of violations, the level of risk at the beginning of the year / at the end of the rating period, the level of risk dynamics, the risk occurrence probability) - table. $1,2$.

Table 1. Risks map in establishing the management functions of the Federal Treasury in the Rostov region Section I "The dynamics of the level of risk" during the year

\begin{tabular}{|c|c|c|c|c|c|c|c|c|c|c|c|c|c|c|c|}
\hline \multirow[b]{3}{*}{ 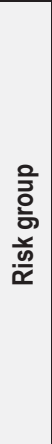 } & \multirow[b]{3}{*}{$\frac{\text { 兹 }}{\underline{\underline{\alpha}}}$} & \multirow{2}{*}{\multicolumn{2}{|c|}{$\begin{array}{l}\text { Risk criteria at the } \\
\text { beginning of the } \\
\text { fiscal year }\end{array}$}} & \multicolumn{12}{|c|}{ Risk criteria during the current fiscal year } \\
\hline & & & & \multicolumn{3}{|c|}{ I quarter } & \multicolumn{3}{|c|}{ II quarter } & \multicolumn{3}{|c|}{ III quarter } & \multicolumn{3}{|c|}{ IV quarter } \\
\hline & & 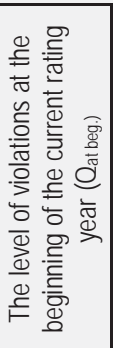 & 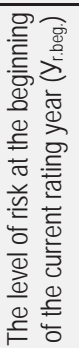 & 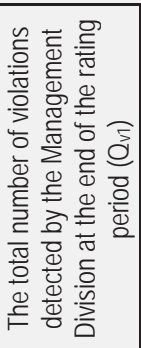 & 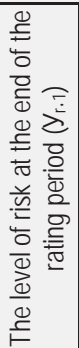 & 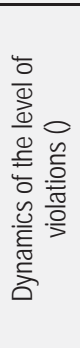 & 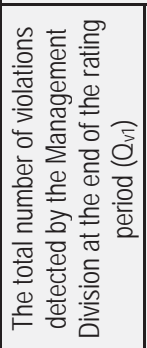 & 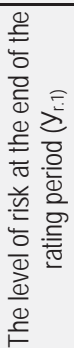 & 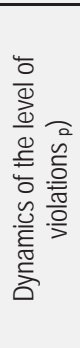 & 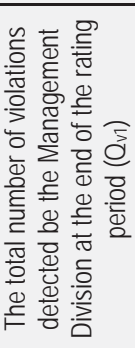 & 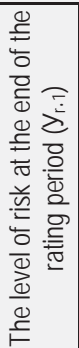 & 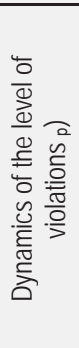 & 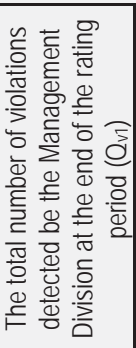 & 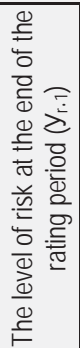 & 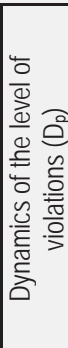 \\
\hline 1 & 2 & 3 & 4 & 5 & 6 & 7 & 8 & 9 & 10 & 11 & 12 & 13 & 14 & 15 & 16 \\
\hline & & & & & & & & & & & & & & & \\
\hline & & & & & & & & & & & & & & & \\
\hline
\end{tabular}


Table 2. Risks map in establishing the management functions of the Federal Treasury in the Rostov region Section II «The number of violations identified by the activity of structural divisions of the Federal Treasury in the Rostov region in the context of the risk and the probability of their occurrence" Risks criterion

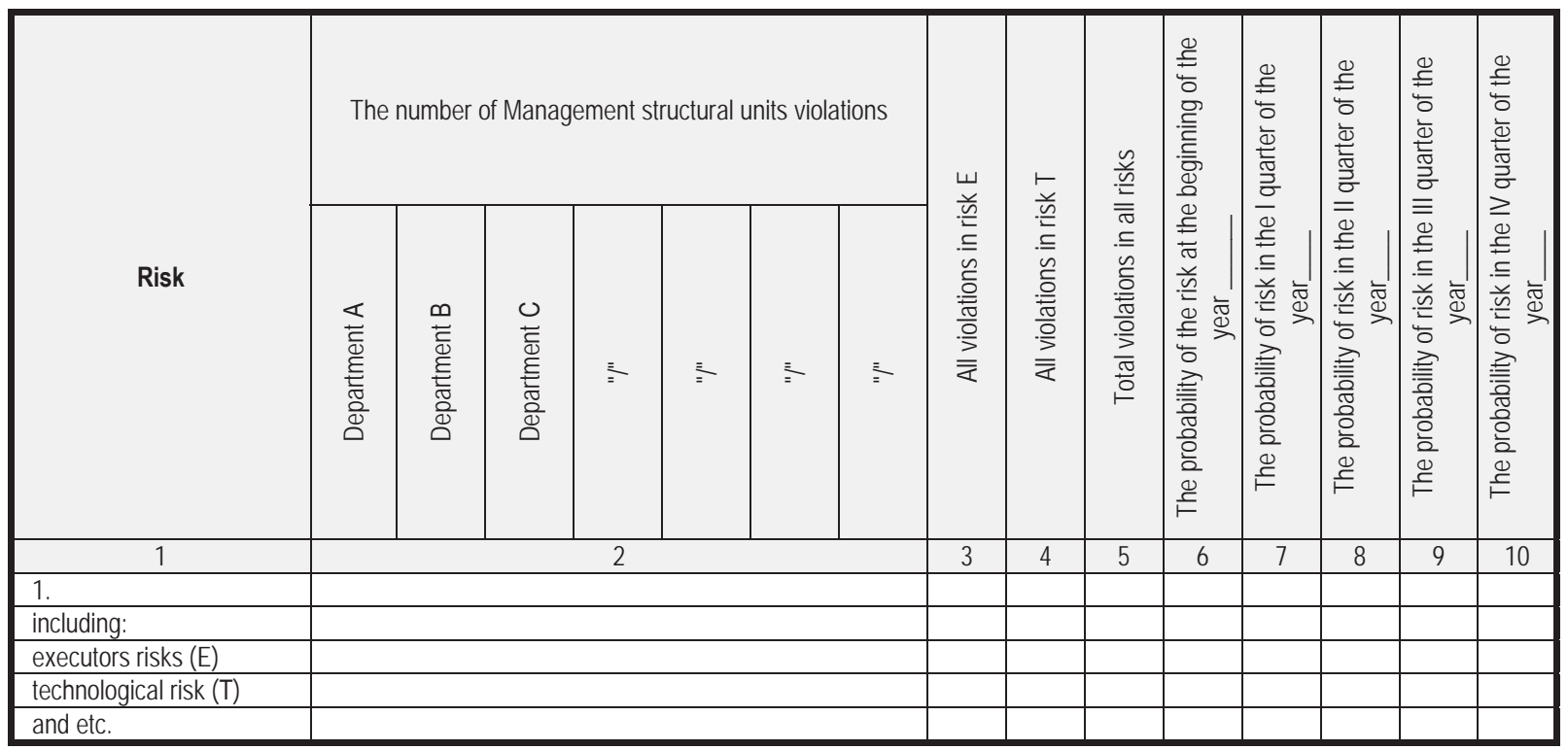

The level of risk depends on the probability of its occurrence and possible consequences.

The definition of the level of violations at the beginning of the current year is defined as the averaged quarterly on the basis of data for the previous rating year violations.

In case of violations absence (data of violations absence), the value of their level at the beginning of the current rating year shall be assessed conventionally equal to 1 .

The definition of the level of risk at the beginning of the current rating year is set relatively according to risk capacitance activities data for the previous rating year.

In case of activity area absence (activities risk capacitance data absence) risk index at the beginning of the current rating year shall be calculated conditionally based on the potential risk capacitance.

To indicate the level of risk the following criteria are used:

- $\quad 50-100 \%$ - a high level of risk (the number of violations detected during the processing of documents handling, operations performing, procedures towards the activities come to more than $50 \%$ of the total number of processed documents, executed operations, procedures);

- $\quad 10-50 \%$ - average risk;

- Up to $10 \%$ - a low level of risk.

Risk criteria are conditional rate.

Analyzing the risk management one uses:

- Comparison method;

- Graphical method.

Quarterly the Department of Internal Control and Audit provides the received analytical information following the results of the end of the rating period to the organization leadership

At that, the Management is in constant search for ways to improve the efficiency of functions performance under the limits of credentials and mechanisms for their implementation.

So, there are three main points related to risks management and their minimization.

In this regard, the work Performance measurement Getting Results (Hatry, H.P., 1999), in which a scientist G. Hatry indicates the state programs efficiency indicators during the monitoring of their effectiveness is of most urgency.

A particular problem of payment system risk monitoring is that the probability of the risk itself is small, but losses in the event of such risks can be enormous for the Treasury and for the whole system, including the national economy. These effects are comparable to the risks related to nuclear stations incidents or natural disasters and catastrophes.

The second payment system feature and characteristics is its high degree of computerization or electronization and system infrastructural dependence based on Internet communications. Improper and unlawful use of communication 
channels can cause movement of funds for criminal purposes. In turn, the necessity of adequate security for the transfers in the system endurance gives rise to various problems.

Finally, the third feature connected with the changing operating environment, which is becoming more difficult for risks detection, assessment and monitoring. Thus, the rapid development of the Internet has opened up wide opportunities for new payment instruments, often operating outside the traditional banking and treasury systems.

\section{Concluding Remarks}

Public finances require constant improvement, especially in the area of the budget funds turnover movement transparency, their turnover acceleration and their usage efficiency.

The examination shows that there are many methods for effective public financial management, ensuring the anticrisis program execution of budget expenditures reductions that benefit state run public authorities, taxpayers, banks and the economy as a whole.

In accordance with the objectives set out in the scientific paper studied the structure of modern methods of creating a single treasury account to eliminate the problems associated with the timely estimation of the state treasury and liquidity to make informed decisions on its regulation and the simplified many business processes in the area of public financial management.

\section{References}

Peacock, S., 2008. An Evaluation of Program Budgeting and Marginal Analysis Applied in South Australian Hospitals. - Melbourne 56 pp.

Premchand, A., 1994. Managing Public Expenditure / A. Premchand. - Washington: IMF. 101 pp.

Treasury Single Account: Concept, Design, and Implementation Issues. Access to the document text: Official website of IMF URL: http://www.imf.org/external/pubs/ft/wp/2010/wp10143.pdf.

Emelianenko, A.V., 2011. Treasury Single Account Liquidity Management - Cash Planning, magazine "Budget.

Evolving theories of public budgeting J. R. Bartle (ed.). - Oxford: Elsevier. 69 pp.

Artyuhin R.E., 2014. Strategic Approach / R.E. Artyuhin//Budget.

Shubina, L.V., 2013. Treasury Single Account Liquidity Management and the risks of its cash balance management estimation (website)/ L.V. Shubina// Finances. - 2013. - №8: RSE "Consultant plus": Legialation: Versia Prof. - Access mode: http://base.consultant.ru/ cons/cgi/online.cgi?req=doc;base=PBI;n=198919.

Syarheenka N.S., 2014. Implementation of Banking Technology in the Organization of Budget Execution // Science, Education and Spirituality in the Context of Sustainable Development: Collection of scientific works of the All-Russian scientific-practical conference, February 28 - March 1, 2014 - Ukhta: USTU, 2014. 197-201 pp.

Barilari, A. and M. Bouvier, 2010. La LOLF et la nouvelle gouvernance fi nanciére de L'Etat. - 3 éd. - P.: LGDJ. 98 pp.

Hatry, H.P., 1999. Performance measurement: Getting results/H.P.Hatry. - Washington, D.C.: The Urban Institute Press. 29pp. 